\title{
NOTES ON THE GENUS ANERISTUS HOWARD WITH DESCRIPTIONS OF NEW SPECIES
}

\author{
(Aymenoptera: Chalcidoidea)
}

By HERBERT L. DOZIER

Formerly Chief of the Division of Entomology, Insular Experiment Station, Río Piedras, Porto Rico.

The purpose of this paper is to establish as clearly as possible the status of the genus Aneristus Howard, to assemble all the available information concerning the habits and host-relationships of its members, and to make known three new species from the West Indies. So far as lnown all the species of Aneristus are primary parasites of the non-diaspine Coccidae or soft scale insects and are of great economic importance.

Aneristus ceroplastae How. is one of the most important enemies of soft scales in the West Indies and is widely distributed throughout the tropies. It does not confine its attack to any one species but is recorded as having been reared from at least six different genera. Aneristus youngi Girault has been reared from two different genera. in Louisiana. A. mangiferae Dozier and asterolecanii Dozier appear to confine their attack principally to the Mango Soft Scale, Coccus mangiferae (Green), and the Golden Asterolecanium, A. aureum Boisd, respectively, and are known only from the West Indies.

Compere in his recent "Revision of the species of Coccophagus" 1 points out that the genus Coccophagus is imperfectly defined and that the characters used to separate this from Aneristus, Prospaltella and certain 'other allied genera are relative and cannot be sharply defined. The few species of Aneristus described to date have been distinguished from those of Coccophagus by having a row of short stiff bristles behind on the flattened posterior tibiae, and a distinctly compressed funicle. In true Coccophagus the hind tibia is normal with the row of distinct bristles lacking, and the flagellum is fusiformly subcylindrical, the funicle joints usually plainly longer than wide. In addition all recorded species of Aneristus where both sexes are known, have the forewing of the female hyaline with a distinct infumation on the discal portion while the male forewing is entirely hyaline.

In 1915 Silvestri erected the genus Prococcophagns, based on the

\footnotetext{
1 Proc. U. S. National Museum, rol. 78, art. 7 , pp, 1-132, pls. 1-14, 1930.
} 
female sex of the new species, Prococcophagus varius Silv. ${ }^{2}$, stating that the new genus could be separated from Coccophagus by the differences in the head, dorsum, greater length, by having the antennae inserted a short distance from the clypeal margin, and by the large compressed scape. The two new species described in this paper as A. hispaniolae and asterolecanii clearly fall into Prococcophagus but grade into Aneristus if the concept of that genus be broadened to include those species with the scape much flattened or foliaceous. In the writer's opinion Prococcophagus must fall as a synonym of Aneristus which, however, seems sufficiently distinct from Coccophagus to be retained. The last-mentioned genus seems very closely connected to Aneristus by such species as Coccophagus modestus Silv., bivittatus Compere, and argenteus Gir. Compere states that the last species has unusual wings, unlike any other described Coccophagus.

Girault in 1917 -(Ins. Inse. Menstruus, vol. 5, p. 37) synonymized his genus Tanaeostigmoidella with Prococcophagus Silv.

The following characterization of the genus Aneristus has been broadened to include those species with the scape dilated or foliaceous. In certain species such as $A$. ceroplastae, croconotus, mangiferae, and oculatipennis a conspicuous group of strong setae are present at the proximal end of the middle tibia; in others such as hispaniolae and asterolecanii these are lacking. A minute study of the chaetotaxy of all the species should be made when further material of certain species becomes available.

\section{The genus Aneristus Howard}

Aneristus Howard, The Canadian Entomologist, vol. 27, 1895.

Characterization.-Closest to Coccophagus. Antennae eight-joint, with a very minute ring-joint, barely discernible under high magnification, present in the female sex between the pedicel and first funicle joint; the scape is distinctly compressed and in certain species is more or less foliaceous; a longitudinal carina is usually present on the scape, dividing the inner portion which regularly forms the scape from an outer more foliaceous extension; the club well-defined, distinctly three-jointed; very characteristic longitudinal elevations or sensoria are present on the club and the funicle joints, although sometimes lacking on the first funicle; these sensoria are particularly prominent in the male. Eyes setose. Forewings with the marginal vein longer than the submarginal, a fuscous cloud generally present with the female but lacking in the male. Hind tibiae flat, with a row of short, stiff bristles behind; the hind femora somewhat thickened; middle tibial spur long and slender, almost as long as the first tarsal joint; all tarsi five-jointed. Internal parasites of the Soft or non-diaspine Coccidae.

Gềnotype.-Aneristus ceroplastae Howard.

${ }^{2}$ Descrizione di nuove Imenotteri Chalcididi africani, Bol. Lab. Zool. Portici, vol. IX, pp. $359-360,1915$. 
Key to females of Aneristus.

1. Scape distinctly widened or foliaceous

Scape not unusually widened-_- 2

2. Dominant color dark, submetallic, the prescutum concolorous_-_-_-_-_-_-_ 8

Dominant color lighter, the prescutum marked with yellow_-_-_-_-_-_-_-_ 3

3. Prescutum with lemon-yellow blotch; forewings with large infumed area extending completely across the wing. Africa_________croconotus Waterston

Prescutum with a wide yellowish band across the middle; forewing with a very narrow infumed area, not reaching across the wing. Haiti, Santo Do-

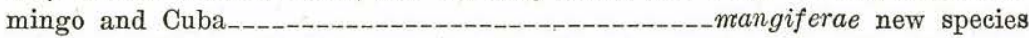

Prescutum with a yellowish-white band; forewing with a three-fourths complete circular infumed ring. Peru and Panama______oculatipennis Girault

6. Third funicle joint brown, the upper third white. Haiti--asterolecanii new : pecies

Third funicle joint entirely whitish___- 7

7. Forewings with a wide hairless or bare area running longitudinally along the lower margin from the base to one-half the length of the forewing. Haiti. hispaniolae new species

Forewings without this hairless area. Africa varius Silvestri

8. Black without distinct purplish reflections, the coxae pale; head more or less and the scape yellowish. Louisiana___-____-_-_oungi Girault

Black, with purplish reflections, scape pale, the head and coxae black. Widely

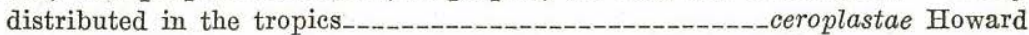

Wholly dark metallic purple, the legs and antennae dark except most of the first tibiae, distal half of the middle tibiae, and the tarsi, which are yellowishwhite; proximal half of the middle tibiae black; 'forewings with a large infumed area, its proximal margin obliquely truncate from about the proximal third or more of the marginal vein. Australia_-fumosipennis Girault \& Dodd

Wholly dark metallic purple, the legs and antennae dark except the scape and cephalic knees and tibiae which are white and all middle tibiae except slightly just distad of the knee; infumed spot on forewings shorter, its proximal margin straight. Australia___________________diabolicus Girault

The writer has not seen specimens of $A$. croconotus Waterston, fumosipennis Girault \& Dodd, varius Silvestri, and diabolicus Girault and these species are included in the above key based on characters included in the original descriptions. To date the males of only three species are known, namely, ceroplastae Howard, croconotus Waterston, and asterolecanii Dozier.

Aneristus mangiferae, new species.

Closest in coloration to $A$. croconotus Waterston but has the infumed area of the forewings decidedly narrower than in that species.

Female. Length $1.02 \mathrm{~mm}$; expanse $1.72 \mathrm{~mm}$.; greatest width of forewing $0.301 \mathrm{~mm}$. General color of head and thorax yellowish-orange, the pronotum, scutellum, axillae, lower part of the scapulae, and the abdomen submetallic dark brown to black; a prominent yellowish band runs across the prescutum and upper portion of the scapulae, the anterior and posterior margins of the preseutum narrowly fuscous. Eyes dark. Ocelli red. Antennae with the scape pale yellowish, 
the pedicel darker, and marked on upper margin with fuseous; the funicle and elub joints smoky. Legs dirty yellowish to slightly smoky, except the slightly paler tarsi, and the dark brown hind, femora and tibiae; the terminal tarsal joints smoky. Forewings with the renation smoky, hyaline; a rather narrow smoky infumation runs downward on the disk extending two-thirds across the width of the wing; this elond starts on its outer margin at the stigmal vein, soon broadening out on the disk; from the stigmal this cloud extends inward to nearly half the length of the marginal vein.

The antenmal seape rather long, compressed but not unusually widened, the pedicel subtriangular; minute ring-joint present; the funicle and elub distinetly compressed, with prominent longitudinal sensoria; the first funicle joint is the longest, twice as long as the pediecl and about a third longer than the second and third subequal funicle joints; the joints nearly subequal in width or only slightly widening to ineluding the first club joint; the lateral margins of each joint somewhat rounded at the ends; this last condition is accentuated in the elub joints, the last two being narrower successively to tip; the shape of the

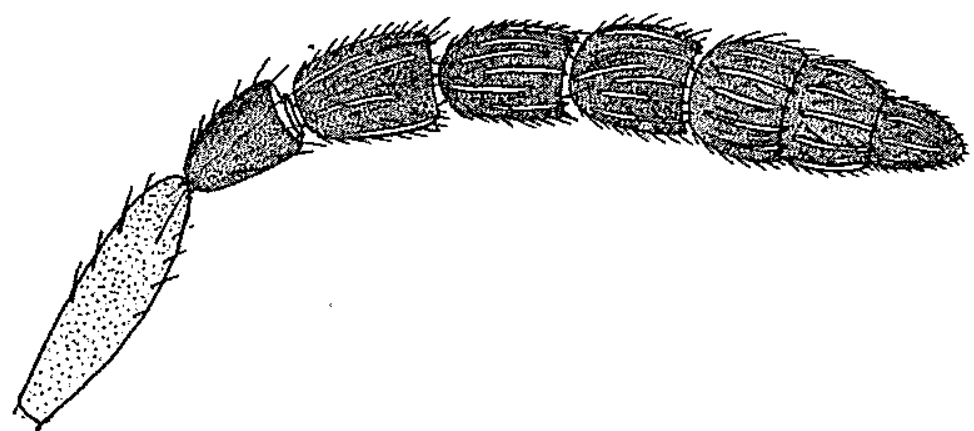

Figure 1.-Antenna of female Aneristus Mangiferae, new speeies, greatly enlarged.

elub is rather distinctive in this speeies; all joints distinetly setose. The vertex, prescutum and seutellum are provided with numerous setae; axillae with a pair of setae; scutellum with a middle pair of small pores, a very strong pair of setae close to the posterior margin and a smaller pair placed anteriorly to these. The dark portions of the head, body and legs minutely reticulated in balsammounted specimens under high magnification. The middle femora supplied with a single prominent black seta near distal end, the middle tibia with a conspicuous group of five blaek setae at the proximal tip. Ovipositor barely exserted, visible in clear, balsam-mounted specimens, extending back to including the third tergite.

Male unknown.

Described from seven females mounted in balsam on slides, reared by the writer from Coccus mangiferae (Green) on mango foliage at Petionville, Haiti, Nov. 19-30, 1930; one female reared by Dr. Giuseppe Russo from Saissetia hemisphaerica (Targ.) at Moca, Republica Dominicana, Mareh 9, 1928 ; and a single female reared by the writer in Haiti from Citrus material received from Cuba, during the course of Eretmocerus serius releases. 
The type female from Haiti is deposited in the U.S. National Museum, Type No. 43807, together with the paratype females from the Dominican Republic and Cuba.

Aneristus ceroplastae Howard.

1895. Canadian Entomologist, vol. 27, p. 350.

1895. Proc. U. S. Nat. Museum, vol. 18, p. 633, Coccophagus orientalis How.

The original description was based only on the female sex, the male being described by the writer in 1927 (Jr. Dept. of Agr. of Porto Rico, vol. IX, no. 4, p. 366, 1925). At that time many rearing records from various hosts were given. In addition the writer has reared the species in Haiti in numbers from Saissetia hemisphaerica on weeds in coffee glade at Fond-des-Negres, March 3, 1930; from Coccus mangifera on mango at Petionville, Dec. 1, 1930; from Coccus viridis on "Cerisier marron", Adelia ricinella, at Petionville, Nov. 8, 1929 ; from Ceroplastes dozieri Cockl. on Maytenus buxifolia at Source Puante, Nov. 19, 1929; and from Icerya sp. on a wild bush known as "Ti buis" on Morne-a-Cabrits, Sept. 10, 1930.

Aneristus oculatipennis Girault.

1916. Psyche, vol. 23, p. 42.

The type and paratype card-pointed material from Peru in the U.S. National Museum has been studied together with the original slide containing head and wing, mounted in balsam. Two specimens reared by J. Zetek at Ancon, Canal Zone, Panama ( $Z$ 2594) in the U.S. National Museum, determined by Mr. A. B. Gahan, agree well with the type and extend the known distribution of the species.

Aneristus youngi Girault.

1917. Descr. Hym. Chale. Var. cum Observ. V, p. 11.

The very brief description of this species appeared in a privately published paper and is given here to make it readily accessible.

"Aneristus youngi. Like Coccophagus modestus Silv. but legs black save hind coxae and first tibia, all tarsi; head more or less and scape yellow; scutelIum hairy. From Ceroplastes chrysanthemum Baton Rouge, La., September, E. S. Tueker. Cat. No. 21477."

The type material, consisting of three card-pointed specimens, has been examined. These were reared from Ceroplastes sp: on chrysanthemum, evidently from either C. cirripediformis or floridensis, the only two species of Ceroplastes recorded from Louisiana. A specimen, reared by the writer from Saissetia hemisphaerica at New Orleans, La., Sept. 16, 1922 (Q-21511) and a specimen from Cocous hesperi- 
dum on citrus at New Orleans, Jan. 15, 1926 agree exactly with the type. The last-mentioned specimen is mounted in balsam on a slide and a photomicrograph of its forewing is shown. The record of $A$. ceroplastae from Louisiana given by the writer in his paper on "An Outbreak of the Red-striped Sugar-Cane Scale" (Jour. Dept. Agr. of Porto Rico, vol IX, no. 4) was based on this specimen and is erroneous. Aneristus youngi Gir. ean easily be distinguished from ceroplastae How. by its black color, lacking the distinct metallic purplish reflections of that species, by the pale coxae, by having the middle tibiae fuscous, and the infumed area of the forewing is distinctly narrower.

Aneristus hispaniolae, new species.

A large, well-marked and distinct species, easily recognized by its peculiar coloration and very foliaceous seape. In width of seape this species is closest to Aneristus varius Silv.

Female. Length $.946 \mathrm{~mm}$; expanse $1.56 \mathrm{~mm}$; greatest width of forewing $0.237 \mathrm{~mm}$. General color of the head and thorax orange, the ground color of

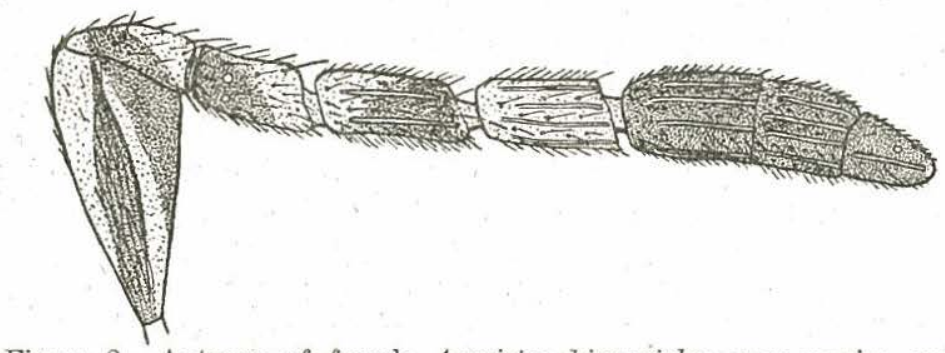

Figure 2.-Antenna of female Aneristus hispaniolae, new species, greatly enlarged.

the abdomen a pale yellowish-white with a broken band of black on each segment, leaving a pale colored median longitudinal area running from the dark brown endophragma to just before a line parallel with the vibrissal plates; under high magnification, the black areas appear more or less distinctly reticulated; legs pale testaceous, the proximal tips of the middle and hind tibiae and the terminal tarsal joints are very faintly marked with fuscous, scarcely noticeable. Ground color of antennae pale with the club brown; on the scape is a longitudinal stripe of brown along the middle and the outer widened part is distinctly infuscated; basal two-thirds of the first funicle joint and the lower half of the second are irregularly and somewhat obliquely infuseated. Eyes black.

Antennae eight-jointed, long. ventrally articulated, composed of scape, pedicel, a very minute ring-joint, three funicle joints and three-jointed elub; the scape characteristically greatly widened or foliaceous, the inner part elongately reticulated; pedicel somewhat triangular, the funicle joints cut off obliquely on their inner half; all joints furnished with prominent setae; those joints forming 
the club and the distal two funicle ones have longitudinal elevations or sensoria; the first funicle joint lacks these but is supplied near its base with two or three pale blister-like circular areas. Eyes setose. The head, thorax, and sides of the abdomen have numerous prominent dark setae. Forewings with a very short marginal fringe of cilia; the setae are very prominent and heavy, contrasting with a wide area running longitudinally along the lower margin from the base to one-half the length of the forewing and a wide area following the apical part of the wing, which appear to be bare or hairless areas on account of the transparent setae. Femora of middle legs with a long seta on posterior margin near the tip; all tarsi five-jointed. The brown ovipositor slightly exserted, visible for its entire length in balsam-mounted specimen, extending to the middle of the fourth tergite.

Male unknown.

Described from a single female, mounted in balsam 'on slide, reared by the writer from a giant wax scale, Ceroplastes giganteus Dozier, on branches of wild fig tree, Ficus rubricosta Warb. at Source Cazeau, Haiti, April 16, 1930.

The type slide is deposited in the U.S. National Museum, No. 43808.

Aneristus asterolecanii, new species.

Very closely related to $A$. hispaniolae Dozier, but the female is easily separated by its smaller size, less widened scape, and difference in coloration of the antennae.

Female. Length $0.803 \mathrm{~mm}$; expanse $1.28 \mathrm{~mm}$; greatest width of forewing $0.201 \mathrm{~mm}$. General color a pale yellowish-white, marked with brown. The pronotum, disk of the axillae, and the lower margin of the scutellum, dark brown; the remainder of the thorax except the pale discal portions of the prescutum and scutellum, of a reddish-orange color; endophragma dark brown; under direct light, the pale portions of the prescutum, scapulae, scutellum, and the endophragma appear to reflect distinctly iridescent hyaline. Antennal ground color pale, the lower or posterior two-thirds of the pedicel, and of the three funicle joints brown; the club brown except the extreme tip which is pale; the scape pale except a comparatively narrow longitudinal brown strip along the middle. The eyes reflect hyaline. Abdomen of a pale yellowish-white ground color, the posterior half of each segment transversely banded with brown, the anterior one only partial, widely interrupted at the middle. Legs pale, the middle tibiae with two inconspicuous brown spots. The darkened areas of the body and the scape appear under high magnification more or less distinctly reticulated. 
Antennae with the scape distinctly foliaceous, being intermediate in width between $A$. hispaniolae and $A$. magniferae; the pedicel slightly longer than wide, subtriangular; the first funicle joint slightly longer than the pedicel and about two-thirds the length of the second funicle, with two or three small blister-like inconspicuous areas present; third funicle slightly longer than the second and almost the same in width; club three-jointed, each joint successively shorter and narrowing to the blunt tip; prominent longitudinal sensoria present on the second and third funicle joints; a very minute ring-joint is present between the pedicel and the first funicle joint. The antennal joints are ventrally articulated. Eyes prominent, distinctly setose. The vertex, prescutum, and lower portion of the abdomen provided with numerous conspicuous setae; three setae are present on the axillae, the inner seta twice as long as the others; scutellum with posterior pair of setae decidedly stronger than the anterior pair and placed much farther apart; the propodeum with a pair of very long, prominent setae. Forewings very faintly infumed at the middle covering over half the wing area; the tip with hyaline area which extends along the posterior margin from the base outwards to a point nearly half the length of the marginal vein. Hind femora and tibiae compressed, the middle femora supplied with a prominent long seta on the posterior margin towards the tip. The ovipositor only very slightly exserted, extending to the fourth tergite.

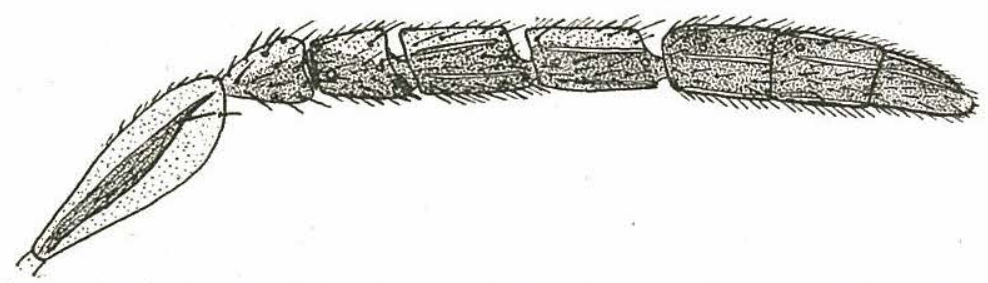

Figure 3.-Antenna of female Aneristus asterolecanii, new species, greatly enlarged

Male. Length 0.574-0.602 mm.; expanse 1.075-1.176 mm.; greatest width of forewing $0.172-0.186 \mathrm{~mm}$. Resembles a Coccophagus. Varies considerably in size. Differs in coloration from that of the female, the vertex and thorax a dark yellowish-orange, the axillae dark. Antennae smoky brown, the basal third of the scape lightened. The propodeum and abdomen distinctly smoky brown. Legs pale, the hind tibiae slightly smoky. Forewings hyaline, lacking the infumation of the female.

Antennae distinctly flattened, ventrally articulated; the scape differing greatly from that of the female, being long and rather slender, only slightly compressed, longer than the pedicel and first funicle joint combined, the longitudinal recticulations faint; the longitudinal carina of the female scape is very indefinite or partial in the male; the minute ring-joint of the female antenna is lacking in the male; the first funicle joint distinctly longer and wider than the pedicel, and only perceptibly shorter than the second and third funicle joints; all joints narrowing successively to the tip of the club; the first club joint the longest; all funicle and club joints provided with prominent setae, and very distinct longitudinal sensoria. The entire area of the forewings are covered with distinct setae, the bare area of the female forewings being lacking. 
Described from two females and seven males, mounted in balsam on slides, reared by the writer from Asterolecanium aureum (Boisd.) on wild Annona sp. on Morne-a-Cabrits, Haiti, May 22-June 1, 1931.

The bolotype female and allotype male are deposited in the U.S. National Museum, No. 43809.

In addition to the above-discussed members of the genus Aneristus, the following species have been described to date from various parts of the world:

Aneristus varius (Silvestri)

1915 Boll. Lab. Zool. Portici, vol. 9, p. 359, Prococcophagus.

Aneristus diabolicus Girault

1915 Mem. Queensland Museum, vol. 4, p. 65

Aneristus fumosipennis Girault \& Dodd

1915 Mem. Queensland Museum, vol. 4, p. 64

Aneristus croconotus Waterston

1917 Bul. Ent. Research, vol. 7, pt 3, p. 234

Table of recorded species of Aneristus and their known hosts.

\begin{tabular}{|c|c|c|c|}
\hline Nam & me of the species & Known distribution & Hosts \\
\hline Aneristus & ceroplastae Howard & $\begin{array}{l}\text { West Indies, Cey- } \\
\text { lon, Java and } \\
\text { Hawaii }\end{array}$ & $\begin{array}{l}\text { Saissetia hemisphaerica(Targ), } \\
\text { Coccus mangiferae (Green), } \\
\text { Ceroplastes actiniformis Green, } \\
\text { C. dozieri Cockerell, Pulvina- } \\
\text { ria iceryi Guerin, Coccus viri- } \\
\text { dis (Green), Eucalymnatus } \\
\text { tesselatus (Signoret), Saisse- } \\
\text { tia nigra (Nietn.), Icerya sp. }\end{array}$ \\
\hline Aneristus & asterolecanii Dozier & Haiti & $\begin{array}{l}\text { Asterolecanium aureum Bois- } \\
\text { duval. }\end{array}$ \\
\hline Aneristus & youngi Girault & Louisiana & $\begin{array}{l}\text { Ceroplastes sp., Saissetia hem- } \\
\text { isphaerica (Targ.), Coccus } \\
\text { hesperidum Linn. }\end{array}$ \\
\hline Aneristus & hispaniolae Dozier & Haiti & Ceroplastes giganteus Dozier \\
\hline Aneristus & oculatipennis Girault & Peru and Panama & Saissetia oleae (Bernard). \\
\hline Aneristus & varius (Silvestri) & Eritrea, Africa & Unknown. \\
\hline Aneristus & croconotus Waterston & Gold Coast, Africa & Lecanium sp. \\
\hline Aneristus & mangiferae Dozier & $\begin{array}{l}\text { Haiti, Santo Do- } \\
\text { mingo, Cuba }\end{array}$ & $\begin{array}{l}\text { Coccus mangiferae (Green), } \\
\text { Saissetia hemisphaerica } \\
\text { (Targ.) }\end{array}$ \\
\hline $\begin{array}{l}\text { Aneristus } \\
\text { Aneristus }\end{array}$ & $\begin{array}{l}\text { diabolicus Girault } \\
\text { fumosipennis Girault }\end{array}$ & $\begin{array}{l}\text { Australia } \\
\text { Australia }\end{array}$ & $\begin{array}{l}\text { Unknown. } \\
\text { Unknown. }\end{array}$ \\
\hline
\end{tabular}

$\&$ Dood

\section{Explanation of Plates}

The photomicrographs used in Plates I and II were secured from the U.S. Bureau of Entomology and are the work of the Bureau 
102 THE JOURNAL OF THE DEPARTMENT OF AGRICULTURE OF P. $\mathrm{R}$.

photographer, Mr. J. G. Pratt, and the writer wishes to herewith express his appreciation.

$$
\text { PLATE XI }
$$

Forewing of female Aneristus oculatipennis Girault, paratype wing, U. S. National Museum Type No. 19211.

F'orewing of female Aneristus youngi Girault, female reared from Coccus hesperidum, New Orleans, La.

Forewing of female Aneristus ceroplastae Howard, from paratype of Coccophagus orientalis Howard, U. S. National Museum Type No. 6905 .

\section{PLATE XII}

Forewing of female Aneristus mangiferae Dozier, paratype female, U. S. National Museum Type No. 43807.

Frorewing of female Aneristus hispaniolae Dozier, type female, U. S. National Museum Type No. 43808.

Forewing of female Aneristus asterolecanii Dozier, paratype female, U. S. National Museum Type No. 43809. 
PLATE XI

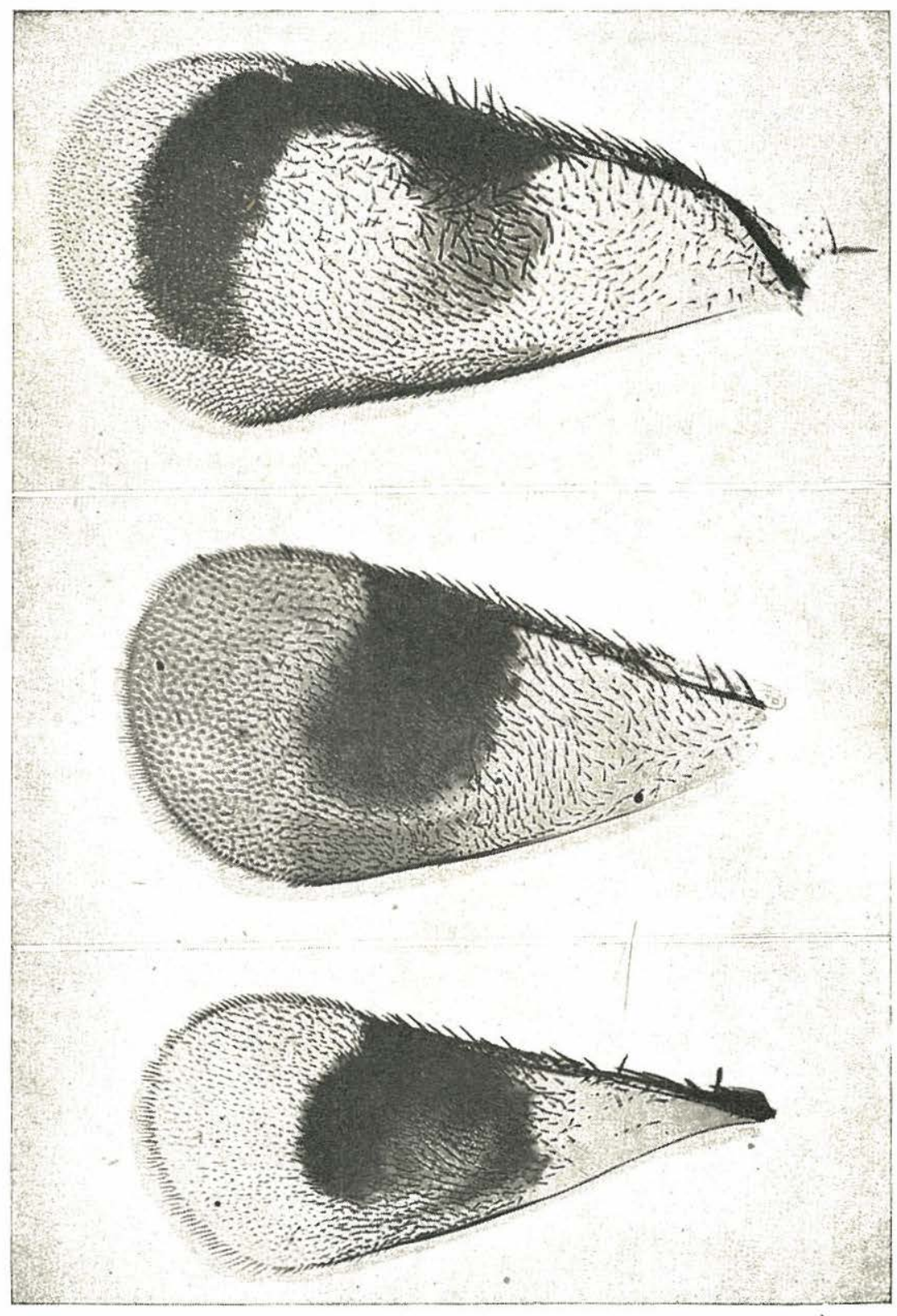


PLATE XII

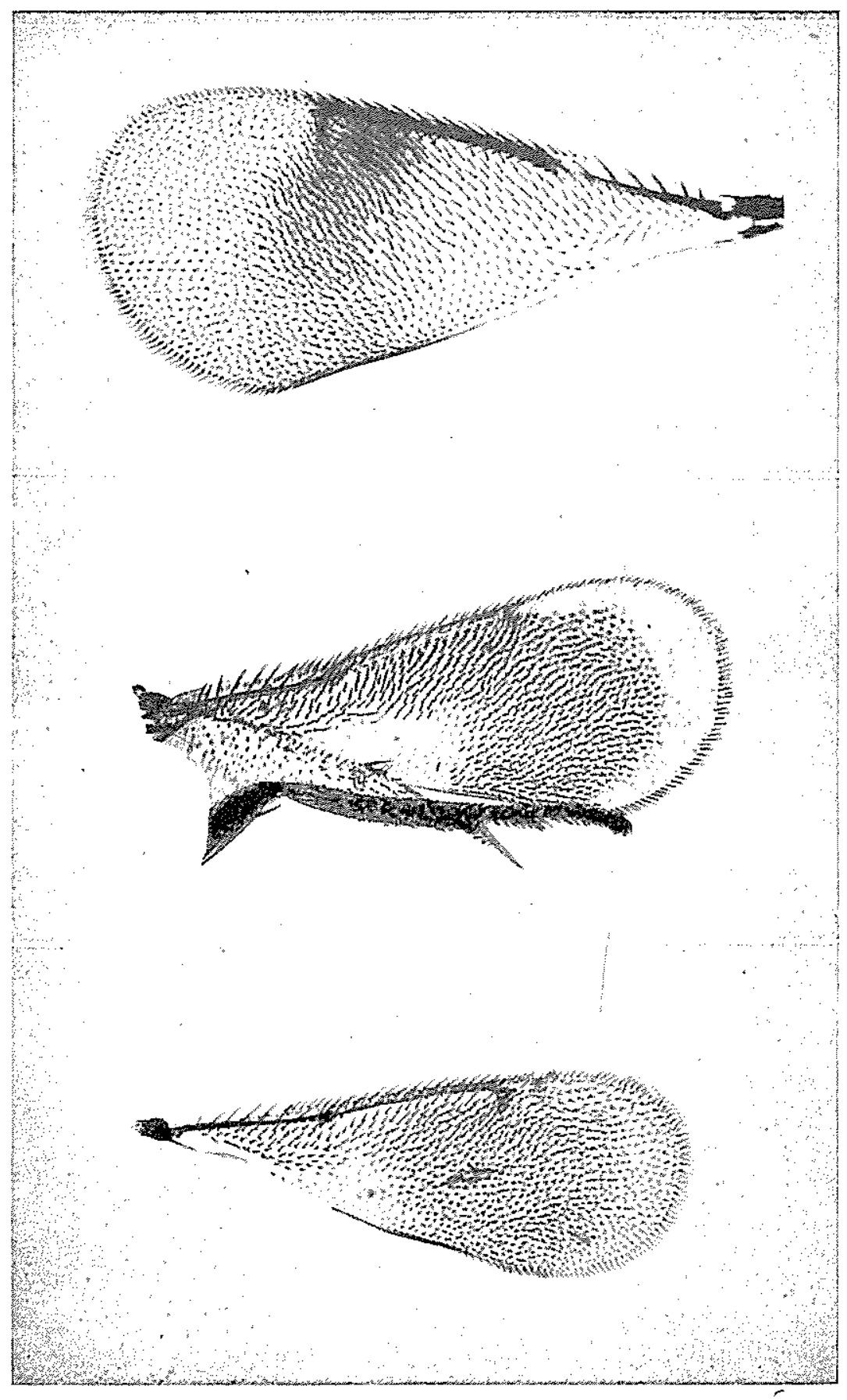

